Meta

Journal des traducteurs

Translators' Journal

\title{
The Translation of Cultural Referents: From Reference to Mental Representation
}

\section{Laura Santamaria}

Volume 55, numéro 3, septembre 2010

URI : https://id.erudit.org/iderudit/045068ar

DOI : https://doi.org/10.7202/045068ar

Aller au sommaire du numéro

Éditeur(s)

Les Presses de l'Université de Montréal

ISSN

0026-0452 (imprimé)

1492-1421 (numérique)

Découvrir la revue

Citer cet article

Santamaria, L. (2010). The Translation of Cultural Referents: From Reference to Mental Representation. Meta, 55(3), 516-528. https://doi.org/10.7202/045068ar
Résumé de l'article

Le présent article a pour objet l'information cognitive portée par les référents culturels et propose une stratégie multidisciplinaire visant à comprendre comment un public cible appréhende ces derniers. L'hypothèse de travail est que les référents culturels sont utilisés dans les oeuvres de fiction (telles que les sitcoms télévisées dont sont tirés les exemples) pour que le public cible associe les personnages avec un contexte socioculturel donné. Selon les techniques de traduction employées, le public cible de la version traduite devrait faire un effort plus important que celui de la version originale et certaines informations ne seront pas retrouvées. L'identification des phases clés de ce processus cognitif constitue une aide pour le traducteur. 


\title{
The Translation of Cultural Referents: From Reference to Mental Representation
}

\author{
LAURA SANTAMARIA \\ Universitat Autònoma de Barcelona, Barcelona, Spain \\ laura.santamaria@uab.cat
}

\begin{abstract}
RÉSUMÉ
Le présent article a pour objet l'information cognitive portée par les référents culturels et propose une stratégie multidisciplinaire visant à comprendre comment un public cible appréhende ces derniers. L'hypothèse de travail est que les référents culturels sont utilisés dans les œuvres de fiction (telles que les sitcoms télévisées dont sont tirés les exemples) pour que le public cible associe les personnages avec un contexte socioculturel donné. Selon les techniques de traduction employées, le public cible de la version traduite devrait faire un effort plus important que celui de la version originale et certaines informations ne seront pas retrouvées. L'identification des phases clés de ce processus cognitif constitue une aide pour le traducteur.
\end{abstract}

\begin{abstract}
This article explores the cognitive information carried by cultural referents and presents a multidisciplinary approach to understanding how target audiences grasp them. I depart from the assumption that cultural referents are used in works of fiction - the examples presented here are taken from a TV sitcom - to allow the target audience to associate characters with a given sociocultural environment. Depending on the techniques used in the translation the individuals will need to make a greater effort than the target audience of the original text and some information will not be appropriately retrieved. It can help the translator to identify the critical phases in this cognitive process.
\end{abstract}

\section{MOTS-CLÉS/KEYWORDS}

référent culturel, œuvre de fiction, représentation sociale, médias, pragmatique cultural referent, fiction work, social representation, medias, pragmatics

For some years now, translation studies have been concerned with cultural and crosscultural aspects of translation (Alvárez and Vidal 1996; Bassnett and Lefevere 1998; Schäffner and Adab 1997). In this context, interest has also grown in cultural references and translation procedures for their successful transfer. However, rather than view cultural references in terms of the difficulty they pose to the translator, this paper aims to explore the kind of information they provide us with about the persons associated with them.

This approach will be based on the premise that cultural references are used by the creators of fictional texts to make the target audience associate each character with a detailed socio-cultural environment and to give them specific personality traits. Alongside the dialect or language variety chosen by the program maker for each character, cultural references serve to enable viewers to identify the social group to which he or she belongs (Santamaria 2000; 2001). This strategy is quite similar to our way of conversing with others. Thus, the subjects of conversation of other speakers (their frames of reference, whether car races, their children or the world's 
environmental problems) trigger our mental representation of their personalities, and above all of the social group to which they belong.

Since the aim of this paper is to characterize culturemes in the light of their function in fiction, cultural referents will be taken to mean /culturemes/, essentially /realia/, which reflect the speaker's personality, and which fulfill an expressive function within the text. The term cultural referents will be therefore used to refer specifically to those culturemes or cultural references which are objects (in the widest sense of the term - see Vermeer 1983, Nedegaard-Larsen 1993 and Nord 1997) and which have a distinctive cultural capital, within the society as a whole, and which are capable of influencing the expressive value which we assign to the individuals who are associated with them. The present study is specifically intended to explore the kind of cognitive information provided by translations of cultural references, through examination of the cognitive effort which must be made by the target audience when the distance between the two cultures is an obstacle to information transfer.

In order to trace the various phases of the process enabling a reference to be associated with a given social representation, we shall examine a number of cultural references which are typical of those occurring in television programs. TV dialogues are especially suited for analysis for a number of reasons.

Firstly, certain translation techniques (for example explicitation) cannot readily be employed, due to the need to condense information (see Díaz Cintas 1997, Gottlieb 1993 and Kovacic 1993), and, especially in the case of subtitles, due to the difference between what the audience can hear in the original dialogues and what they can read on the screen, other translation procedures cannot be used (such as situation and cultural adaptation, to use the terminology used by Nedegaard-Larsen 1993). In this sense, the task set in this survey is to distinguish between the foreignization-naturalization dichotomy as far as the translation of cultural references is concerned. Secondly, despite the fact that only verbal elements of the entire oral-visual total are translated, viewers infer information from the non-verbal elements as well, which contributes to understanding of the text itself.

Let us start with a brief dialogue from the North American series The Nanny which was translated into Catalan. This series, broadcast in U.S. between 1993 and 1999, portrays the day-to-day life of a woman (Fran Fine, played by Fran Drescher) from Queens, and who, after breaking up with her fiancé for whom she used to work as a bridal consultant, takes up door-to-door sales. This is how she meets the recentlywidowed Broadway producer, Maxwell Sheffield (Charles Shaughnessy), who hires her as a nanny to look after his three children.

In this particular episode, Stock Tip, from the 1994-1995 run, Fran takes Maxwell Sheffield's youngest child to the supermarket to show her that you can judge a man's marriage ability by the products he buys. Fran then meets a man at the supermarket, Glen (Corbin Bernsen) who tells her that he works on Wall Street. Later, Glen convinces Maxwell to make certain investments, but Fran discovers that Glen is a hot dog vendor on Wall Street (and not a stockbroker) and she must now find a way of ensuring that Maxwell does not follow his investment advice.

(1) Fran: Everything you need to know about a man you can find it right in his cart. If there's a box of Midol, keep moving. Corn pads means he lives with his mother. 
Learned that part the hard way. And if you see two guys with sweaters tied around their neck buying pesto, save yourself the pain.

$[\ldots]$

Glen: Oh, excuse me (bumping his cart into Fran's).

[...]

Fran: Now, let's see. I see bacon, Virginia ham... Well, I know one thing, you're not a rabbi.

Glen: My cover is blown.

[...]

Fran: So, we've ruled out rabbi and I can tell you're not a lawyer.

Glen: Why I can't pass as a lawyer?

Fran: Well, not in New York, I mean maybe in L.A.

Glen: I work on Wall Street. ${ }^{1}$

(The Nanny - Stock Tip 1994)

In this brief extract, a number of supermarket products and items of clothing are cultural references in keeping with the definition presented above. The cognitive associations drawn from them which allow Fran to relate the various objects to social classifications of men in her setting are presented in table 1.

TABLE 1

Cognitive inference of Cultural Referents in English and Spanish

\begin{tabular}{|c|c|c|c|}
\hline $\begin{array}{l}\text { Supermarket } \\
\text { items (original } \\
\text { text) }\end{array}$ & $\begin{array}{c}\text { Supermarket } \\
\text { items (translated } \\
\text { text) }\end{array}$ & $\begin{array}{l}\text { Meaning in } \\
\text { social setting }\end{array}$ & Cognitive inference \\
\hline Midol & $\begin{array}{l}\text { Compreses } \\
\text { (sanitary pads) }^{2}\end{array}$ & Married men & $\begin{array}{l}\text { Men do not use these products; they } \\
\text { buy them for someone with whom } \\
\text { they have a close relationship. }\end{array}$ \\
\hline Corn pads & $\begin{array}{l}\text { Tiretes per als ulls } \\
\text { de poll }\end{array}$ & $\begin{array}{l}\text { They live with } \\
\text { their mother }\end{array}$ & $\begin{array}{l}\text { This item is associated with older } \\
\text { people; it enables viewers to imagine } \\
\text { the relationship between them and } \\
\text { the person they buy it for. }\end{array}$ \\
\hline $\begin{array}{l}\text { Two guys with } \\
\text { sweaters tied } \\
\text { around their neck } \\
\text { buying pesto }\end{array}$ & $\begin{array}{l}\text { Dos paios amb un } \\
\text { jersei lligat al coll } \\
\text { que compren pesto }\end{array}$ & $\begin{array}{l}\text { They are } \\
\text { homosexual }\end{array}$ & $\begin{array}{l}\text { Two men go shopping together to } \\
\text { buy a product they will later share at } \\
\text { home; their way of dressing } \\
\text { corroborates the stereotype. }\end{array}$ \\
\hline Pork meat & Carn de porc & $\begin{array}{l}\text { They are not } \\
\text { rabbis }\end{array}$ & Practising Jews do not eat pork. \\
\hline "no tie"3 & "no tie" & $\begin{array}{l}\text { They are not } \\
\text { lawyers }\end{array}$ & Lawyers dress in a certain way. \\
\hline
\end{tabular}

The figure below outlines the process by which we associate certain items with given social values, in other words, how cultural referents can be linked to social representations: 
FIGURE 1

From cultural referent to mental representation in translation 1 - General model

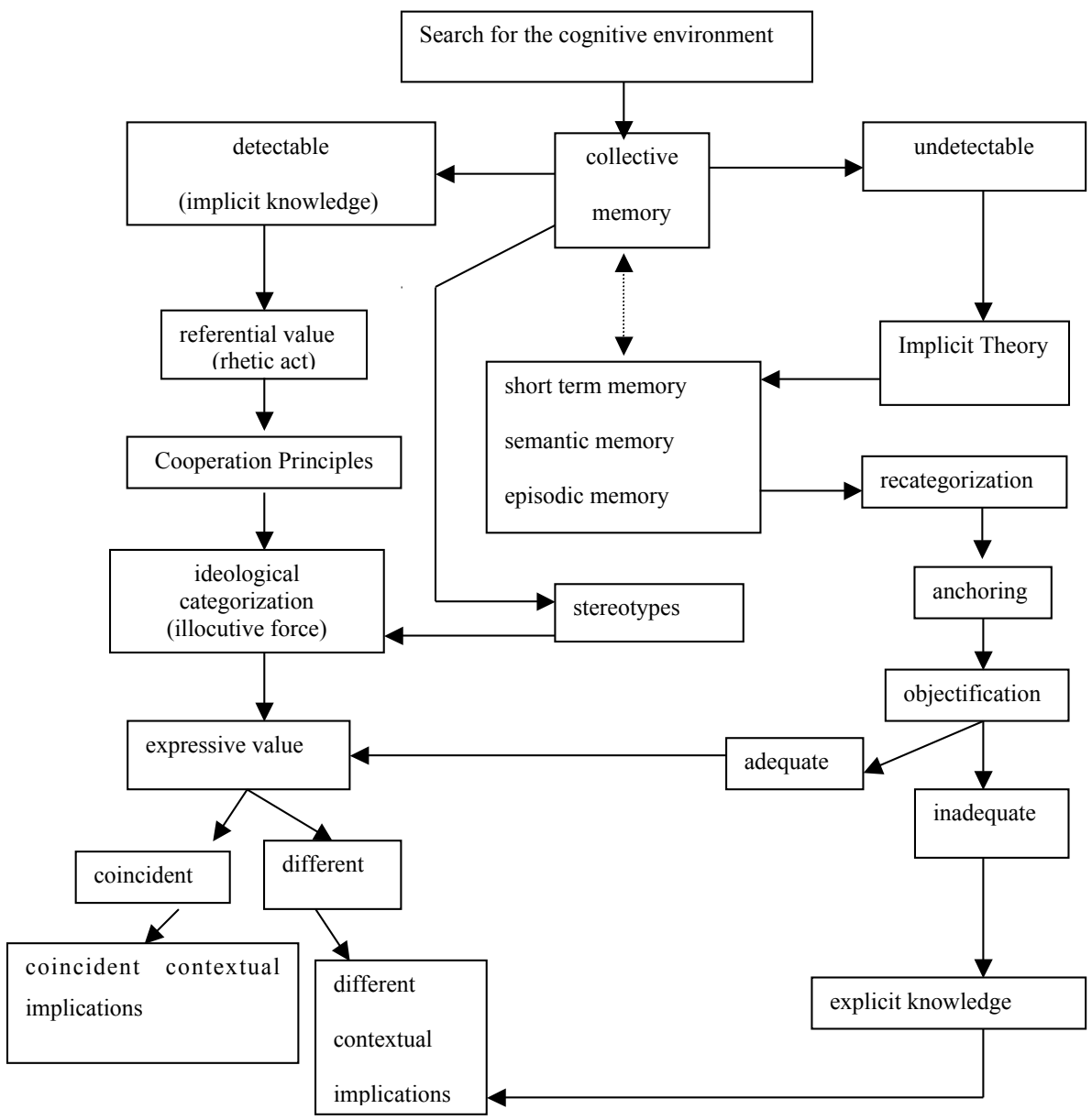

As shown in figure 1, the association between the referent and the representation may not always be equally successful. Depending on the cultural distance involved, the new target audience may be more or less successful in establishing the connection.

The interpretation process presented can be illustrated in different ways, in accordance with the amount of knowledge available to the target viewers concerning the referent. Figure 2 presents in detail how the cultural referent becomes a mental representation when the relevant information is found in the collective memory. 


\section{FIGURE 2}

From cultural referent to mental representation in translation 2 - Detectable environment and implicit knowledge

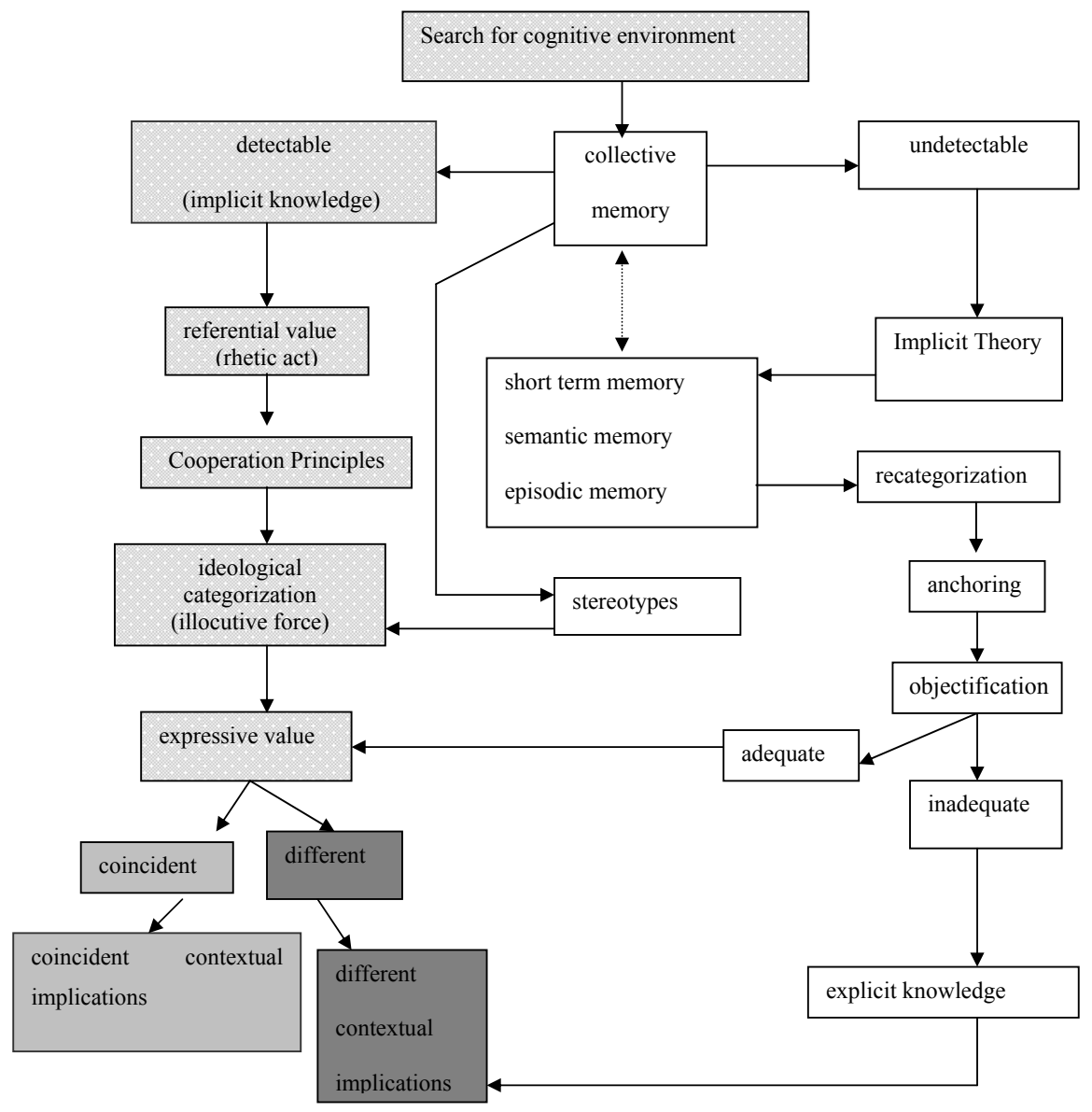

Firstly, it is necessary to detect the cognitive environment. Cognitive environment (Sperber and Wilson 1986) is here meant to be a variable psychological concept established by speakers to help them to understand the context in which an utterance is produced (in this case, the context in which the phrases corn pads, Midol, two guys buying pesto, pork and the meaning of men not wearing a tie are generated: Fran goes to the supermarket on the lookout for a potential husband; this information we have already been given).

A vital role in this process is played by the ability to locate the necessary data in the collective memory (i.e., shared information determined internally by the group and through which the group wants to appear before others; Halbwachs 1968).

However, the information stored in collective memory also receives inputs from short-term memory (Lundh 1983), or period of time while meaning structures are 
active, semantic memory (van Dijk 1998), or knowledge of the world, and episodic memory (van Dijk 1998), which retains the memory of the events experienced personally.

In the first examples (Midol / compreses and corn pads / tiretes per als ulls de poll), the cognitive environment can be detected, that is, the collective memory of the text's potential target audience contains sufficient information to interpret both referents. In fact, the information is implicit since the cultural referent, a speech act within the speech act of the actual utterance, is a rhetic act which succeeds in conveying meaning and reference in individuals (Austin 1962: 95).

In this sense, cultural referents are communication units with illocutive and perlocutive force, capable, in Grice's (1967/1989) terms, of generating conversational implications. In this phase, Grice's Cooperation Principles serve to describe how viewers, speakers themselves, employ certain learned mechanisms to attribute meaning to utterances, and thus establish links between Midol / compreses and corn pads / tiretes per als ulls de poll and groups of people in society which can be categorised on an ideological basis.

The illocutive force of referents establishes the nexus between the referent attributed to a character and the world the television programme wants to portray. The referent then becomes a mark of group identification which, as in real life, is associated with certain values which are particular to a given group and which serve the double purpose of identifying group members both to themselves and to others. In other words, the referents used by the Nanny identify individuals as members of groups, but they also serve to identify the Nanny herself, since by means of these referents she expresses her opinion of these groups to which she is external.

The first step in understanding the influence in a given society of foreign cultural elements imported in translation, in this case television translation, is to define the structure of social organization.

Societies implicitly involve social fragmentation (Berger and Luckmann 1995), since they include groups which define themselves in terms of differences from other groups. The desire to maintain and increase cultural capital leads to internal conflict which results in the hegemony of certain groups over others and permits overall social cohesion.

This hegemony of certain groups, those holding the dominant ideology, is facilitated by the capacity of societies to create symbolic structures with their own value systems which serve to provide cohesion, since the various groups comprising the society see themselves as sharing a set of common beliefs.

Cultural referents, as symbolic forms particular to specific groups, are not exempt from this ideological categorization, ${ }^{4}$ and this must be borne in mind by the translator. Setting out from the premise that referents are resources employed by those who create fiction in order to characterize characters as individuals within a given social group, we can then postulate that scriptwriters must be confident that viewers will be able to recover the referential and expressive information associated with these referents.

As socialised individuals, we draw on referents to categorize our interlocutors in real life. Therefore, we can argue that we apply the same strategies when interpreting fictional texts because the real world is a learning source that applies to fiction as well. 
When the rhetic link enabling ideological categorization cannot be established due to cultural distance between the original and the target culture, the translator must intervene at this stage of ideological categorization to adjust the character's social environment in such a way that the target audience can now attribute a coincident expressive value to the referent.

To verify the nature of the ideological link established with the cultural referent, Santamaria (2000) suggests the following classification of cultural references ${ }^{5}$, highlighting the cultural capital of each:

TABLE 2

\section{Classification of Cultural Referents}

\begin{tabular}{|l|l|}
\hline Ideological category & Commodities \\
\hline Ecology & Referents associated with personal experience of the environment \\
\hline History & Referents associated with social meaning deposits \\
\hline Social Structure & $\begin{array}{l}\text { Referents associated with environments related to the production of } \\
\text { meaning }\end{array}$ \\
\hline Cultural Institutions & $\begin{array}{l}\text { Referents associated with environments related to the propagation of } \\
\text { meaning }\end{array}$ \\
\hline Social Universe & Referents associated with manifestations of social meaning \\
\hline Material Culture & Products associated with the cultural manifestations of given groups \\
\hline
\end{tabular}

Table 2 presents the ideological analysis demanded in the translation process. The translator's task is to gauge whether the translation will enable the target audience to recognize the referent and whether the expressive value derived on the basis of their previous knowledge will coincide with or differ from the original. It is in this phase - during the transformation from cultural referent into mental representation - that translation decisions play an especially important role.

In summary then, the first partial success lies in identifying the information associated with the referent in the viewer's memory. Social fragmentation may lead to a situation whereby for individuals within certain groups, the knowledge associated with a referent is implicit and may have been acquired unconsciously. This inclines the individual to perceive in a given way and to have a socially learned attitude (people who buy Midol / compreses or corn pads / tiretes per als ulls de poll are not likely marriage candidates in the world of the Nanny). Aided by common sense or the knowledge taken for granted, the individual will attribute an expressive value to the referent which will be very similar to the value attributed by other members of his or her group, with whom he or she shares the same set of social representations.

Therefore, the key difference between the cultural elements which individuals have to interpret stems from the origin of the cultural referent. If the referents are one's own, the associated knowledge is implicit, and the associated referential value is called up unconsciously, and ideological categorization then takes place on the basis of the values of the individual's ideology. If these values coincide, they lead to contextual implications which also coincide and which serve to define the fictional characters. If the values are different, then the implications will also be different and the message may well be lost.

The process shown in figure 3 corresponds to those cases where target viewers need to resort to stereotypes to have to derive some information from the cultural referent. 
FIGURE 3

From cultural referent to mental representation in translation 3 - Detectable environment and explicit knowledge

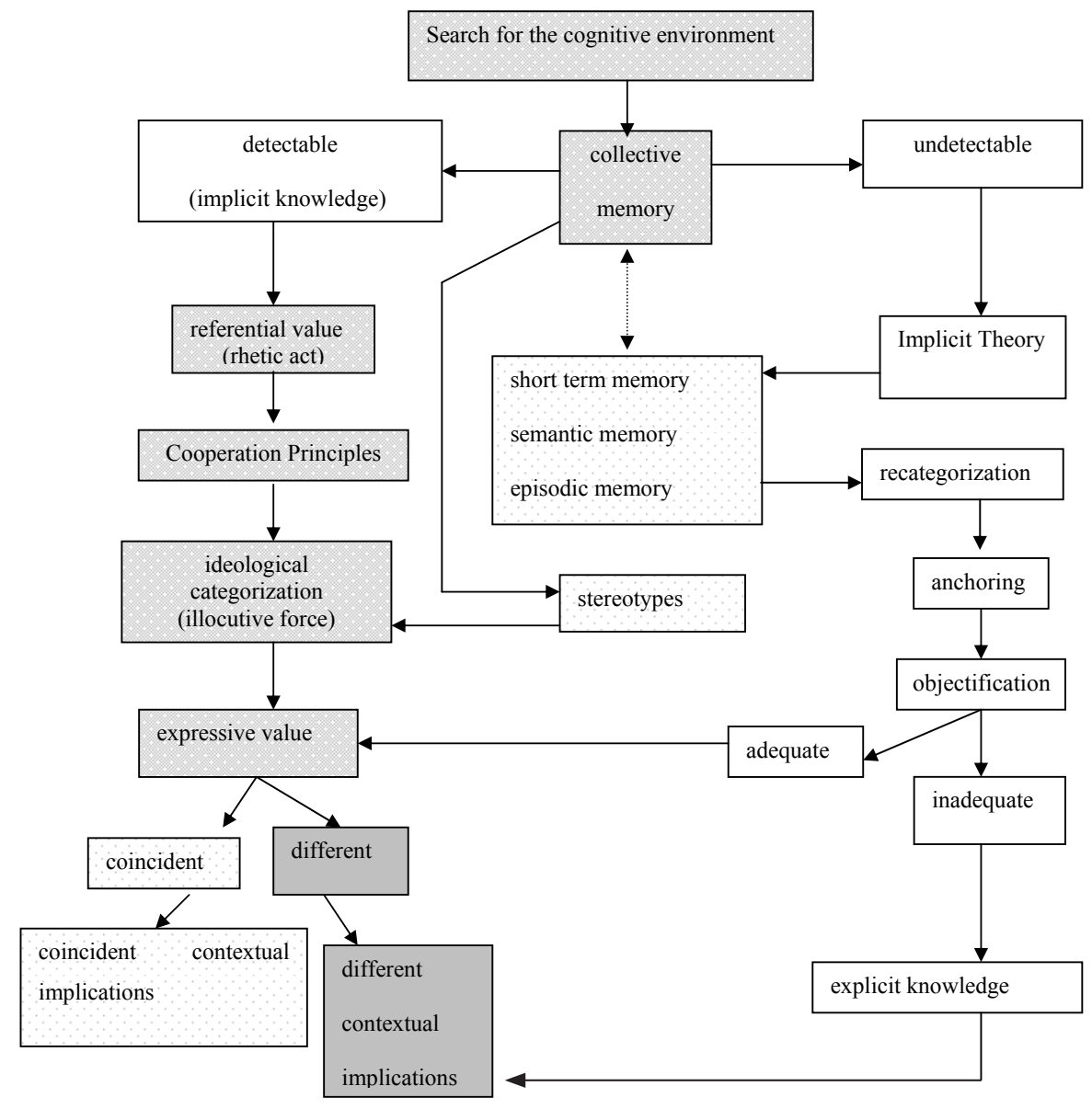

Before going back to analyzing the transformation of the cultural referent into social representation, let us consider another example in which Fran, the Nanny, relates given referents to certain values. According to her, "two guys with sweaters tied around their neck buying pesto" are homosexuals. In this case, the referents act together to convey a given stereotype, which triggers off certain information in the collective memory, but which may be modified through, for example, personal contact (episodic memory). This is how our beliefs concerning other groups are modified. The concept of stereotype (Tajfel 1981) is closely related to the concept of memory and it could be said that each interplays with the other (since episodic memory has a varying effect on the values generated in the collective memory by given referents). 
From a positive view of the concept of stereotypes, we can say that their objective is to permit individuals to gain in knowledge. We learn from previous knowledge (stereotypes) and we store information related to the stereotypes in the other types of memory.

Several authors (see Tajfel 1981: 156; Duveen and Lloyd 1993: 92) relate stereotypes to the human need to simplify the complex data coming from the world around us. These data, often biased in nature, must be simplified if humans are to understand it.

There is also an element of personal justification in the way we define others. Stereotypes may serve to justify our behavior and attitudes towards other groups, and this is what lies at the root of our perception of stereotypes as a negative phenomenon.

Audiovisual translation relates two culturally different worlds, the world in which the original text is generated and the world of the target audience. One important question is then, to what extent translation in general, and audiovisual translation in particular, can modify the beliefs and values of the new target audience.

If this episode of The Nanny were to be translated into Italian, perhaps we would find that pesto would not trigger the same associations among the target audience, since it would not be seen as a sophisticated product and would not, therefore, be associated with homosexuals under the terms of the prevailing stereotype which portrays them as having more sophisticated tastes than the usual male.

At this stage, the referent undergoes a process of ideological categorization, the output of which will be an expressive value. The expressive value may either coincide with that generated among the original target audience, in which case it will lead to coincident contextual implications, or it may differ, in which case the contextual implications will also differ.

It must also be borne in mind that acquisition of knowledge is not only a social process, but also a personal one (van Dijk 1998), which is why we present this last process (figure 4).

To exemplify this point, let us return to The Nanny. Once Fran and Glen have met at the supermarket, Fran comments that Glen cannot be a rabbi since he has bought pork products. This comment will almost certainly surprise viewers of the translated script, but not the original target audience. The Nanny website tells us that Fran has a strong nasal Jewish accent, but no matter whether the program is subtitled or dubbed, this feature will not be significant to the new target audience. If dubbed, it may be that the target culture has no linguistic variety which is clearly associated with Jews, and if subtitled, there is no clear-cut way to convey such features in written language.

Non-U.S. viewers may also have difficulty with the connection between not wearing a tie and being a lawyer in Los Angeles, but not in New York. The viewers' collective memory does not have information on this difference and unless the data allowing Fran to express this opinion is extended, the referent is likely to get lost in the translation.

These examples highlight the differences between each audience's background knowledge. The new target audience does not have sufficient data in collective memory to interpret the reference. 
FIGURE 4

From cultural referent to mental representation in translation 4 - Undetectable environment

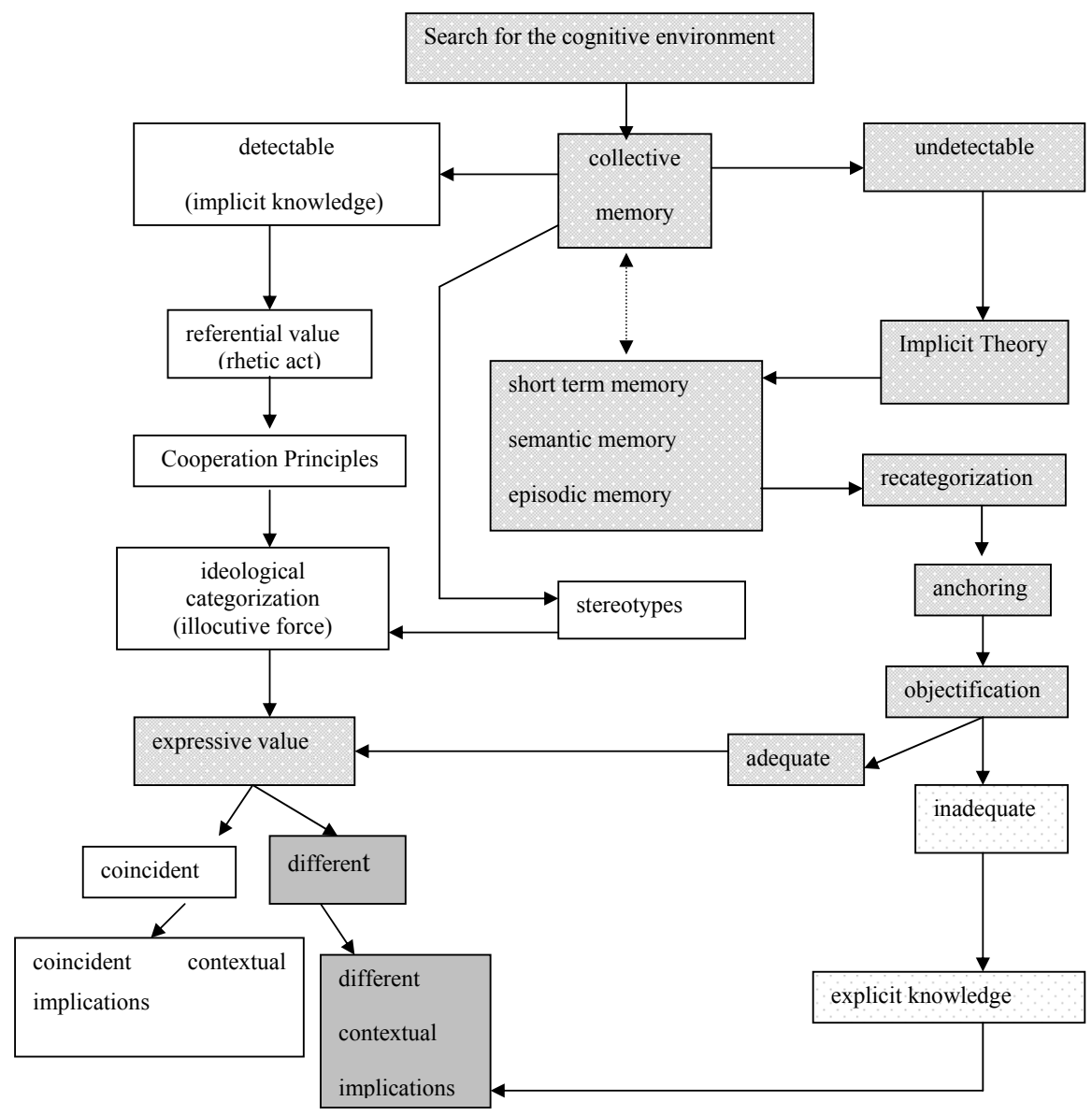

If these target viewers of the translated text are to infer further information from these two comments, they will have to make a greater effort in order to categorize whatever is different from their acquired experience patterns.

Whether the viewer will make this personal effort or not will depend on such immediate personal factors as tiredness, and also personality traits and the individual's intellectual capacity to understand a given situation.

Therefore, the model proposed here to account for how cultural referents become mental representations must also include personal readiness to accept new information and convert it into a representation. Thus, Roloff and Berger's Implicit Theory (1982: 17) serves to account for personal attitude, before the anchoring and objectification phases (Moscovici 1984). 
1) Implicit motivation theory: how people try to understand what causes behavior;

2) Implicit personality theory: how people see personal attributes as related to each other;

3) Implicit abnormal psychology theory: the others are good or bad;

4) Expectations people have about relationships.

In this case, the viewer will integrate the new data into the previously acquired structure of social representations.

Cognitive integration of the new representation occurs in two stages. In the first stage, anchoring (Moscovici 1984: 29), the new element, the cultural referent, is compared with recognized elements in the individual's paradigm of representations to integrate it. We invariably try to associate everything alien with familiar categories and images. This operation is quite frequent when interpreting foreignizing texts.

In the second phase, objectification (Moscovici 1984: 38), an imprecise idea is invested with an iconic quality; in other words, an effort is made to reproduce a concept as an image. This process however, is visible, unlike common-sense processing, which takes place invisibly.

As shown in the chart above, the result of the objectification phase may either be adequate or inadequate.

If in the process of objectification, the translated referent is associated to a concept with differences in relation to the parameters in the original text, it will never have the opportunity to acquire a similar expressive value; the explicit knowledge deriving from it will differ from that intended by the script (or in certain cases, such as Fran's judgment of Glen by his clothes, it may not generate any pertinent knowledge among the target audience) and the contextual implications will, of course, also be different.

On the other hand, if the outcome of the objectification phase is adequate, an expressive value is attributed to the referent (concluding that perhaps dress styles vary between lawyers in New York and Los Angeles; or that Fran must be a Jew from other evidence provided in this episode and the series as a whole), although it may be different and may lead to different contextual implications due to the fact that this knowledge is not implicit and does not form part of the social knowledge taken for granted.

This paper has consciously avoided proposing translation strategies for cultural referents, since the choice of strategies will depend on the function and nature of the translation in question. Rather, my purpose has been to explore how translation of referents can influence identification of fictional characters.

I have considered the processing phases which enable the target audience to generate mental representations of the characters on the basis of the cultural referents associated with them.

Insights from such varied disciplines as translation studies, cultural studies, pragmatics and cognitive studies, have allowed us to speculate on how cultural references become referents which serve to identify groups within society; bearing in mind that society attributes individuals with different cultural capital, and that this is known to all members of society, and very often transmitted linguistically.

The task of adapting the cultural referent to the knowledge of the target audience falls to the translator. If a decision is made to employ calques and loans, the cognitive effort required of the target audience increases, as does their knowledge of the other culture. Were this process to be applied equally to all exchanges involving translation, 
it would undoubtedly facilitate the emergence of more plural societies, despite the symbolic violence which occurs with the incursion of translation into any given social setting.

\section{NOTES}

1. Also, the mistaken interpretation of working on Wall Street as synonymous with being a stockbroker could serve as a basis for study of the inferences drawn from cultural references. Similarly, the fact that Fran is sure that Glen cannot be a lawyer and the fact that Corbin Bernsen, who plays Glen, is also a lawyer in the L.A. Law series could provide the basis for analysis of the interplay between fiction and reality often found in such programmes.

2. The actual product changes in translation, but the contextual implications are the same.

3. There is no explicit linguistic information regarding this point, it is clear from the images.

4. In Santamaria (2000), we have described how it is in this phase that we find the mediation of the translation, and also how it is here that we can analyse the translation procedures. In the present example, the replacement of Midol (a brandname that would mean nothing to the new target audience) with another product which is only used by women.

5. The same article describes why the author has discarded previous classifications such as those of Newmark (1988) and Nida (1975).

\section{REFERENCES}

Alvárez, Roman and Vidal, M. Carmen-África (1996): Translation, Power, Subversion. Topics in Translation. Vol. 8. Clevendon: Multilingual Matters.

Austin (1962): How To Do Things with Words. Cambridge: Harvard University Press.

Bassnett, Susan and Lefevere, André (1998): Constructing Cultures: Essays on Literary Translation. Topics in Translation. Vol. 11. Clevedon: Multilingual Matters.

Berger, Peter L. and Luckmann, Thomas (1995): Modernity, Pluralism and the Crisis of Meaning. Gütersloh: Bertelsmann Foundation Publishers.

Díaz Cintas, Jorge (1997): El subtitulado en tanto que modalidad de traducción fílmica dentro del marco teórico de los Estudios de Traducción. Doctoral thesis, unpublished. València: Universitat de València.

Duveen, Gerard and Lloyd, Barbara (1993): An ethnographic approach to social representations. In: Glynis M. Brea Kwell and David V. CANTER, eds. Empirical Approaches to Social Representations. Oxford: Clarendon Press, 90-109.

Gottlieb, Henrik (1993): Subtitling: People Translating People. In: Cay Dollerup and Annette LindegaARD, eds. Teaching Translation and Interpreting. Vol 2. Amsterdam: John Benjamins, 261-273.

GrICE, Paul (1967/1989): Studies in the Way of Words. Cambridge: Harvard University Press.

Halbwachs, Maurice (1968): La mémoire collective. Paris: Presses Universitaires de France.

Kovacic, Irena (1993): Relevance as a Factor in Subtitling Reductions. In: Cay Dollerup and Annette Lindega ARD, eds. Teaching Translation and Interpreting. Vol 2. Amsterdam: John Benjamins, 245-251.

Lundh, Lars-Gunnar (1983): Mind and Meaning. Towards a Theory of the Human Mind Considered as a System of Meaning Structures. Studia Psychologica Upsaliensia. Uppsala: Acta Universitatis Upiliensis.

Moscovici, Serge (1984): The phenomenon of social representations. In: Robert M. FARR and Serge Moscovici, eds. Social Representations. Cambridge: CUP, 3-69.

NedergaArd-Larsen, Brigit (1993): Culture-bound Problems in Subtitling. Perspectives. Studies in Translatology. 2:208-241.

Newmark, Peter (1988): A Textbook of Translation. New York: Prentice Hall International.

NidA, Eugene (1975): Componential Analysis of Meaning. An Introduction to Semantic Structures. Paris: Mouton. 
Nord, Christiane (1997): Translating as a Purposeful Activity: Translation Theories Explained. Manchester: St. Jerome.

Roloff, Michael E. and Berger, Charles R., eds. (1982): Social Cognition and Communication. Beverly Hills: Sage.

SANTAMARIA, Laura (2000): Cultural References in Translation: Informative Contribution and Cognitive Values. In: Marily Gaddis Rose, ed. Beyond the Western Tradition. Translation Perspectives. Vol. 11. Binghamton: State University of New York, 415-426.

SANTAMARIA, Laura (2001): Función y traducción de los referentes culturales en subtitulación. In: Lourdes Lorenzo García and Ana Pereira Rodríguez, eds. Traducción subordinada inglés-español/galego II: el subtitulado. Vigo: Universidad de Vigo.

SCHÄFfner, Christina and AdAB, Beverly (1997): Translation as intercultural communication - contact as conflict. In: Mary Snell-Hornby, Zuzana Jettmarová and Klaus KaindL, eds. Translation as Intercultural Communication. Amsterdam: John Benjamins, 325-337.

Sperber, Dan and Wilson, Deirdre (1986): Relevance: Communication and Cognition. Oxford: Blackwell.

TAjfel, Henri (1981): Human Groups and Social Categories. Cambridge: CUP.

van DijK, Teun A. (1998): Ideology. A Multidisciplinary Approach. London: Sage.

Vermeer, Hans (1983): Translation Theory and Linguistics. In: Sonja TirkKonen-Kondit, Pauli RoINILA and Ritua Orfanos, eds. Joensuu: Näkökphtina Känämisen tuckimuksesta Joensuun kokea Koulu, 1-10. 